\title{
Physico-chemical Properties and Heavy Metal Contents of Ino-Capayang Mine-made Lake in Marinduque, Philippines
}

\author{
Jellian L. Lanot ${ }^{1}$, Jhoy Ann L. Lawig ${ }^{1}$, Jayson A. Lecaros ${ }^{1}$, Paul John L. Malagotnot ${ }^{1}$, \\ Panchito M. Labay ${ }^{1}$ and Jessie O. Samaniego ${ }^{2}$ \\ ${ }^{1}$ School of Engineering, Marinduque State College, Tanza, Boac, Marinduque, 4900, Philippines. \\ ${ }^{2}$ Department of Science and Technology - Philippine Nuclear Research Institute, \\ Commonwealth Ave., Quezon City, 1101, Philippines
}

${ }^{2}$ ORCID ID: 0000-0003-1020-6224

\begin{abstract}
Ino-Capayang mine-made lake is a monolith remains of mining in Marinduque, opened in 1968 and closed and abandoned in 1980. The lake is surrounded by barren lands and few vegetation scattered with metallic ores forming acid mine drainage continuously draining into the lake. To evaluate the water quality in the lake, water samples were collected from the lake and analyzed for physico-chemical parameters and heavy metal concentrations. Physico-chemical parameters were $\mathrm{pH}$, temperature, electrical conductivity (EC), total dissolved solids (TDS) and oxidation-reduction potential (ORP) were measured on-site using digital measuring devices while heavy metal concentrations were analysed using flame atomic absorption spectrophotometer (FAAS). Results showed that the water in the lake measured with slightly alkaline $\mathrm{pH}$ (7.83) and mean temperature of $31.74^{\circ} \mathrm{C}$. Measured heavy metal concentrations of $\mathrm{Cd}(<0.006 \mathrm{mg} / \mathrm{L}), \mathrm{Cu}(0.018 \mathrm{mg} / \mathrm{L}), \mathrm{Fe}(0.151 \mathrm{mg} / \mathrm{L}), \mathrm{Pb}$ $(0.0089 \mathrm{mg} / \mathrm{L}), \mathrm{Mn}(0.1404 \mathrm{mg} / \mathrm{L})$ and $\mathrm{Zn}(0.1507 \mathrm{mg} / \mathrm{L})$ were all within the regulated levels for the freshwater can be intended for propagation of fish and other aquatic resources as well as recreational activities such as boating, fishing, and for agriculture use. Other parameters, such as EC and TDS, were measured with lower levels compared to the characteristics of other mine-made lake in the country, while the measured ORP ORP indicates that the entire water in the lake has high oxidizing agent.
\end{abstract}

Keywords: Ino-Capayang, heavy metals, Marinduque, minemade lake, abandoned mines

\section{INTRODUCTION}

In July 1968, the Consolidated Mines Inc. (CMI) started operating an open-pit bench type mining for copper ore production in Mogpog, Marinduque. Ino-Capayang mine is one of the porphyry copper deposits in Philippines which is associated with the western segment of Luzon Arc [1]. Due to the low price of copper in the market and high production cost, the company was closed in August 1980. After the abandonment, Ino-Capayang, one of the open pits created by CMI was filled with water and became a mine-made lake (Fig. 1). The company left a monolith remains of mine-made lake, considered a threat to the environment and to the lives of the people that can pollute the environment any time. Ino-
Capayang is located between villages of Ino and Capayang, which is located around $3.72 \mathrm{~km}$ from the town proper of Mogpog, in the island of Marinduque (Fig. 2).

Currently, the mined-out area excluding the lake is barely covered with vegetation [2] and it has been a site for outdoor activities for people who do biking, walking and shooting. It was reported that the local government of Mogpog, Marinduque is planning to convert the lake and surrounding area into an eco-tourism park, where people can do activities such as walk around the lake, boating or fishing and other outdoor activities. Efforts has been laid out to rehabilitate and bring back the green in the degraded mining area by bioremediation using native plants and their associated microbes of fungi and bacteria [3] as well as ferns, grasses, shrubs and herbs [2]. While trees such as narra, acacia and eucalyptus showed healthy growth in degraded land soil with the help of beneficial fungi and bacteria that strengthen plant tolerance to high acidity and heavy metals present in the soil [4].

Abandoned and inactive mines pose high risks to human health and the environment due to the disturbed and exposed heavy metal-laden soils and sediments and water-filled open pit mines with high heavy metal concentrations. Most of these heavy metals are scattered in the environment through mining that involves removal of large volumes rocks and ore bodies and sometimes the whole mountain [5]. The open-pit mining is used to extract massive deposits of these metals from ores that are at or near the surface and are large in all three dimensions. The method may be used in almost any kind of surface terrain. One of the devastating outcomes of open-pit mining is the pit mine lakes or mine-made lakes that extend below the natural water table [6]. A number of environmental concerns surround pit mine lakes and perhaps the most important concern is the longterm chemical evolution of pit lake water [7] - [9].

The oxidation of rich sulfide mineral ores, such as the scattered pyrite and cuprite ores in the fields lead to the formation of sulfur oxides, which when dissolved in water like rain and runoffs create sulfuric acid, an electrolytic-like solution laden with heavy metal ions. The acidic solution formed can dissolve further the harmful heavy metals and metalloids from the surrounding rocks, releasing more metallic ions, like aluminum, cadmium, copper, iron, lead, manganese, mercury, nickel, silver and zinc [10]. These heavy metals present in the soil and 
water are particularly problematic because they do not break down in the environment [10]. If uncontrolled, the acid mine drainage formed may run-off into streams and leach into groundwater that can affect domestic water supply, which can cause long-term damages to the surroundings.

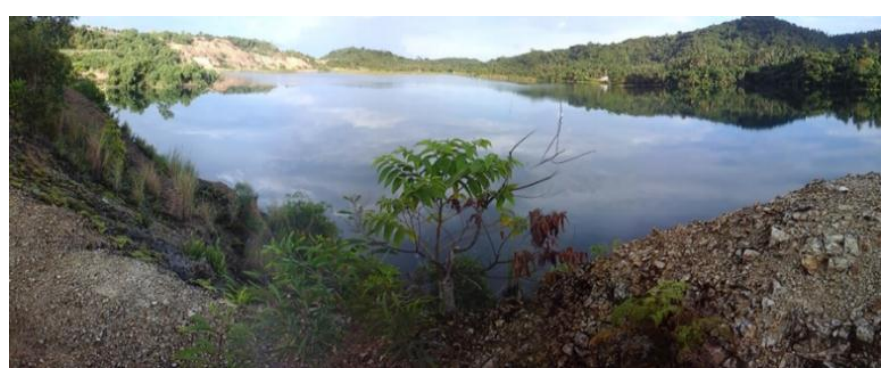

Fig. 1. Ino-Capayang mine-made lake filled with water.

In 2001, Mines and Geosciences Bureau of the Philippines commissioned Tetra Tech EM Inc. (USA) to undertake the conduct of preliminary site assessment of selected twenty-one (21) abandoned mines in the country [4], [11]. The result of the semi-detailed assessment showed that all abandoned mine sites pose environmental risks of varying degrees - from unstable tailings pond, toxic contaminants in the soil and water which may harm human health and the aquatic, terrestrial and wild lives. Ino-Capayang mine-made lake, one of the abandoned mines evaluated, has health risk for $\mathrm{As}, \mathrm{Cu}, \mathrm{Cd}, \mathrm{Hg}, \mathrm{Pb}$, and $\mathrm{Zn}$, hazardous to human beings, plants and animals. The pit area is almost barren and the surroundings have very few surviving vegetation of ferns, grasses, shrubs and trees. The remaining scattered waste rocks and soil samples of the area have phytotoxic levels of $\mathrm{As}, \mathrm{Cu}$ and $\mathrm{Zn}$. The objective of this study is to characterize the physico-chemical parameters and heavy metal concentrations of the mine-made lake in the abandoned Ino-Capayang mined-out area and compare it to the Philippines freshwater classifications for possible use on propagation of fish and other aquatic resources, recreational activities such as boating, fishing, and for agriculture use.

\section{MATERIALS AND METHODS}

\section{II.I Study Area}

The Ino-Capayang open pit copper mine is one of the mining sites in the country that was abandoned and was not rehabilitated after its operation. Ino-Capayang area is fairly flat almost at sea level, except for the scattered rolling hills at the northeastern part. Ino-Capayang mine-made lake is one of the most obvious remnants of the shut downed Consolidated Mines Inc. (CMI), which started its operations in 1968. It is located between Barangay Ino and Capayang in the municipality of

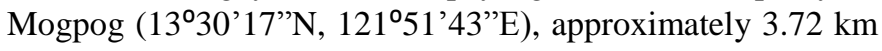
road from the Mogpog town proper in the island of Marinduque (Fig. 2). The lake has a measurement of $0.56 \mathrm{~km}$ east-west and $0.33 \mathrm{~km}$ north-south. The abandoned mine area is situated approximately $1.0 \mathrm{~km}$ east of Tayabas Bay.

\section{II.II Water Sampling and Physico-chemical Measurement}

Water sampling campaigns in Ino-Capayang mine-made lake were conducted in September 2017. Water samples were collected from the specified locations of the lake with exact coordinates plotted evenly in the lake (Fig. 3). A total of twenty-five (25) samples were collected from the upper layer of the lake water and placed in 500-mL amber glass bottles and closed tightly and then placed in a cooler and brought to Marinduque State College - Tissue Culture Laboratory. Water samples were preserved by acidification using $\mathrm{HNO}_{3}(\mathrm{pH} 2)$ and were stored in iced cooler during transport from Marinduque to the Philippine Nuclear Research Institute Laboratory in Quezon City, Metro Manila.

The physico-chemical characteristics of the water samples were determined on site using a multi-parameter Digital $\mathrm{pH}$ Meter Professional 7-in-1 Water Testing Meter $\mathrm{ORP} / \mathrm{pH} / \mathrm{EC} / \mathrm{RH} / \mathrm{CF} / \mathrm{TDS}$ (ppm)/TEMP Tester. This equipment has an electrode for each parameter immersed at the upper layer of the lake water at the same sampling points with direct reading properties on-site.

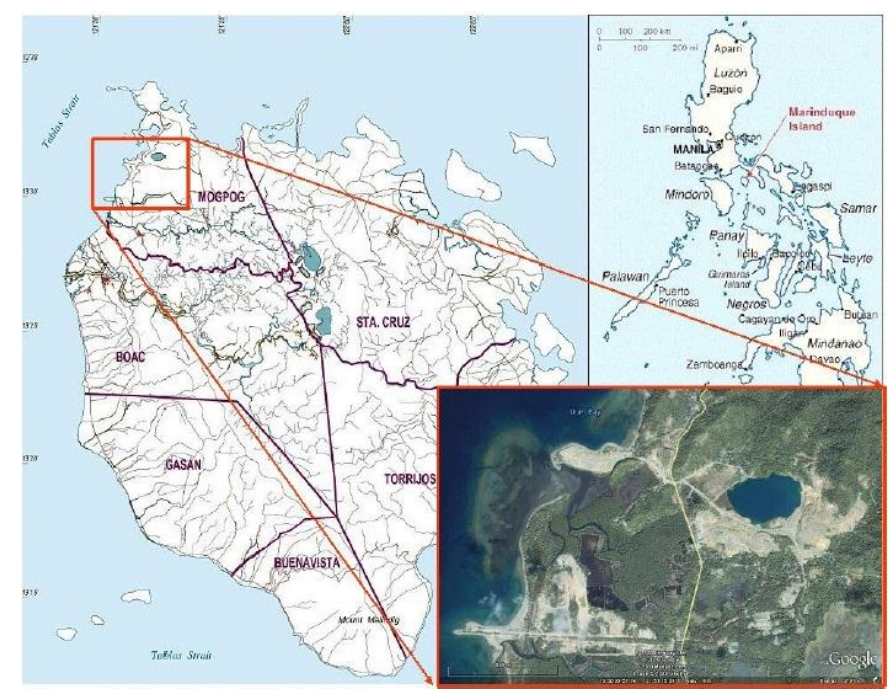

Fig. 2. Location of the study area and the image of the minemade lake (Source: Google Earth). Adopted from [2]

\section{II.III Heavy Metal Analysis}

Water samples from the mine-made lake were analyzed using the Flame Atomic Absorption Spectrophotometer (FAAS) (Varian AA240, USA) at the Philippine Nuclear Research Institute (PNRI) Laboratory in Quezon City, Metro Manila. Heavy metal analyzed were $\mathrm{Cd}, \mathrm{Cu}, \mathrm{Fe}, \mathrm{Pb}, \mathrm{Mn}$, and $\mathrm{Zn}$. APHA-AWWA-WEF Standard Method for the Examination of Water and Wastewater [12] was used as a reference in conducting the analyses. All reported physico-chemical parameters and heavy metal concentrations were the average of 25 samples analyzed.

All physico-chemical parameters and heavy metal concentrations were compared to the freshwater (Class C) quality guidelines [13]. Class $\mathrm{C}$ freshwaters are intended for propagation of fish and other aquatic resources as well as 
recreational activities such as boating, fishing, and for agriculture use.

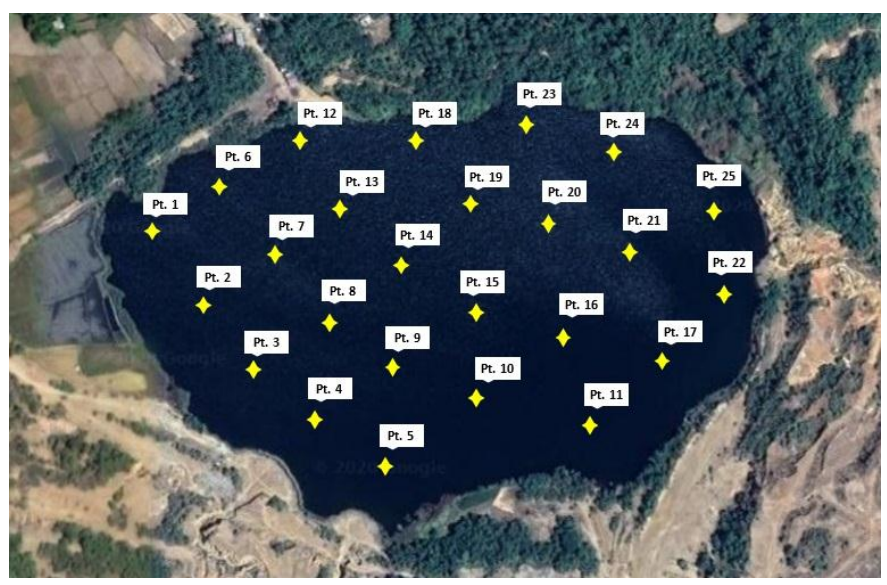

Fig. 3. Sampling points where water samples collected and measured the physi-chemical parameters

\section{RESULTS AND DISCUSSION}

\section{III-I Physico-chemical Characteristics}

The mean concentrations of the measured physico-chemical parameters and its corresponding regulatory limits are presented in Table 1 . High temperature $\left(31.74^{\circ} \mathrm{C}\right)$ observed in the upper layer of the lake is normal where low temperature usually observed in the bottom water (hypolimnion) and increased towards the upper waters (epilimnion) and the atmosphere. Electrical conductivity (EC) in the mine-made lake has low ability to electric current with an average of 0.53 $\mathrm{mS} / \mathrm{cm}$. These values were in agreement with the low total dissolved solids (TDS) at $370 \mathrm{mg} / \mathrm{L}$. Measured EC and TDS in this lake are lower than the measured EC $(0.842-0.912 \mathrm{mS} / \mathrm{cm})$ and TDS $(610 \mathrm{mg} / \mathrm{L})$ in a pit lake of abandoned mercury mine in Palawan island in the Philippines [11], while ORP of the lake water tested has a mean of $267.6 \mathrm{mV}$, which indicate that the entire water has high oxidizing agent such as oxygen. Oxidation-reduction potential is found to be temperaturedependent, therefore a rise in temperature will cause to increase the oxidizing agents in the water.

\section{III-II Heavy Metal Concentrations}

Presented in Table 1 are the result of the analyzed heavy metals and its corresponding regulatory limits for Class $\mathrm{C}$ waters. Results show mean concentration of $\mathrm{Cu}, \mathrm{Pb}, \mathrm{Fe}, \mathrm{Mn}$, and $\mathrm{Zn}$ are $0.018 \pm 0.002 \mathrm{mg} / \mathrm{L}, 0.0089 \pm 0.005 \mathrm{mg} / \mathrm{L}, 0.151 \pm 0.013$ $\mathrm{mg} / \mathrm{L}, 0.1404 \pm 0.002 \mathrm{mg} / \mathrm{L}, 0.1507 \pm 0.013 \mathrm{mg} / \mathrm{L}$, respectively, while $\mathrm{Cd}$ was undetected at $0.0006 \mathrm{mg} / \mathrm{L}$. Iron has the highest concentration among the analyzed heavy metals from the lake water followed by $\mathrm{Zn}, \mathrm{Mn}, \mathrm{Cu}, \mathrm{Pb}$ and the undetected $\mathrm{Cd}$.

Compared to the study at the same lake in 2004 [14], the concentration of $\mathrm{Zn}, \mathrm{Cu}$ and $\mathrm{Mn}$ decreased. The result of the previous study reported that $\mathrm{Cu}(1.68 \mathrm{mg} / \mathrm{L})$ and $\mathrm{Mn}(2.70$ $\mathrm{mg} / \mathrm{L}$ ) concentrations exceeds its respective standard value indicating that the water is harmful and unsafe for domestic and irrigation purposes. This study reveals that the concentration of $\mathrm{Cu}$ and $\mathrm{Mn}$ together with other metals $(\mathrm{Cd}, \mathrm{Fe}, \mathrm{Pb}$ and $\mathrm{Zn})$ are within the standard value indicating that it can be used for propagation of fish and other aquatic resources as well as recreational activities such as boating, fishing, and for agriculture use as stated in DENR standards for Class C freshwaters.

The decrease of heavy metal concentration in the water suggests that the metal ions are adsorbed to the soil or solid particles that settle in the bottom of the lake over time. Several studies reported that heavy metals were positively associated with the fine particles [15] - [17] that are settled in the bottom of the water bodies.

Table 1. Physico-chemical characteristics and heavy metal concentrations of Ino-Capayang mine-made lake with corresponding Philippines water quality guidelines

\begin{tabular}{|l|l|l|l|}
\hline Parameter & Unit & \multicolumn{1}{|c|}{ Mean $($ n=25) } & $\begin{array}{c}\text { Regulatory } \\
\text { Limits for } \\
\text { Freshwater* }\end{array}$ \\
\hline Temperature & ${ }^{\circ} \mathrm{C}$ & $31.74 \pm 0.05$ & $25-31$ \\
\hline $\mathrm{pH}$ & $\mathrm{pH}$ & $7.83 \pm 0.02$ & $7.0-8.5$ \\
\hline $\mathrm{EC}$ & $\mathrm{mS} / \mathrm{cm}$ & 0.53 & - \\
\hline $\mathrm{TDS}$ & $\mathrm{mg} / \mathrm{L}$ & $370 \pm 2.24$ & - \\
\hline $\mathrm{ORP}$ & $\mathrm{mV}$ & $267.6 \pm 1.25$ & - \\
\hline $\mathrm{Cd}$ & $\mathrm{mg} / \mathrm{L}$ & $<0.0006$ & 0.005 \\
\hline $\mathrm{Cu}$ & $\mathrm{mg} / \mathrm{L}$ & $0.018 \pm 0.002$ & 0.02 \\
\hline $\mathrm{Fe}$ & $\mathrm{mg} / \mathrm{L}$ & $0.151 \pm 0.013$ & 1.5 \\
\hline $\mathrm{Pb}$ & $\mathrm{mg} / \mathrm{L}$ & $0.0089 \pm 0.005$ & 0.05 \\
\hline $\mathrm{Mn}$ & $\mathrm{mg} / \mathrm{L}$ & $0.1404 \pm 0.002$ & 0.2 \\
\hline $\mathrm{Zn}$ & $\mathrm{mg} / \mathrm{L}$ & $0.1507 \pm 0.013$ & 2.0 \\
\hline
\end{tabular}

*DENR Administrative Order No. 2016-08 Water Quality Guidelines (Class C)

\section{CONCLUSIONS AND RECOMMENDATION}

Physico-chemical characteristics and heavy metal including $\mathrm{Cu}$ concentrations of the lake water in the Ino-Capayang minemade lake was presented in this study. Out of 5 of the physicochemical parameters analyzed in this study, temperature and $\mathrm{pH}$ are within the regulatory limit. Other physico-chemical parameters, though not regulated, are with low concentrations (EC, TDS) compared to the other abandoned mine pit lake while the positive ORP indicates that the entire water in the lake has high oxidizing agent.

Measured heavy metal concentrations ( $\mathrm{Cd}, \mathrm{Cu}, \mathrm{Fe}, \mathrm{Pb}, \mathrm{Mn}, \mathrm{Zn})$ in the lake water were all within the concentration levels for the regulated Class $\mathrm{C}$ freshwaters. The concentration levels of $\mathrm{Zn}$, $\mathrm{Cu}$ and $\mathrm{Mn}$ in the lake decreased compared to its previous 
measurement in 2004. This suggest that metal ions are attach to the soil particle and settles to the bottom of the lake over time. The values measured in this study suggest that the lake can be used for propagation of fish and other aquatic resources as well as recreational activities such as boating, fishing, and for agriculture use.

Other regulated physico-chemical parameters and heavy metals are recommended to be measured and monitored on this lake in varying season as this mined-out area is being planned to be converted into an eco-tourism park.

\section{ACKNOWLEDGMENT}

The authors acknowledge the Department of Science and Technology - Philippine Nuclear Research Institute for the heavy metal analyses and Marinduque State College - Tissue Culture Laboratory for sample preparations and preservations.

\section{REFERENCES}

[1] U.S. Geological Survey. Porphyry copper deposit in Marinduque, Philippines: Ino-Capayang. 2014. Available at https://mrdata.usgs.gov/sir20105090z/showsir20105090z.php?id=503.

[2] Medianista RL, Labay PM. Phytosuccession and Phytosociology of Plants in Ino-Capayang Mined out Area for Possible Phytoremediation Activities in Marinduque. Proceedings of 4th International Conference on Civil, Environment and Waste Management (CEWM-17) Jan. 23-24, 2017. Manila (Philippines).

[3] Aggangan NS, Anarna JA. Microbial Biofertilizers and Soil Amendments Enhanced Tree Growth and Survival in a Barren Mined-out Area in Marinduque, Philippines. Journal of Environmental Science and Management 2019; 22(2): 77-88.

[4] Aggangan NS, Anarna JA, Cadiz NM. Tree Legume Microbial Symbiosis and Other Soil Amendments as rehabilitation Strategies in Mine Tailings in the Philippines. Philipp. J. Sci. 2019; 148(3): 481-491.

[5] Guilbert JM, Park CF. The Geology of Ore Deposits. Waveland Press, Inc. IL, USA. 2007.

[6] Chávez PC, Uribe Salas JA, Pérez NR, Medina MM, Villanueva RM, Ramos Arroyo YR, Camacho JR. (2010). The impact of mining in the regional ecosystem: the Mining District of El Oro and Tlalpujahua, Mexico. De Re Metallica 2010; 15: 21-34.

[7] Shevenell L, Connors KA, Henry CD. Controls on pit lake water quality at sixteen open-pit mines in Nevada. Applied Geochemistry 1999; 14(5): 669-687.

[8] Tempel RN, Shevenell LA, Lechler P, Price J. Geochemical modeling approach to predicting arsenic concentrations in a mine pit lake. Applied Geochemistry 2000; 15(4): 475-492.
[9] Bowell RJ. The hydrogeochemical dynamics of mine pit lakes. Geological Society London Special Publications 2002; 198(1): 159-185.

[10] Plumlee GS, Morton RA, Boyle TP, Medlin JH, Centeno JA. An Overview of Mining-Related Environmental and Human Health Issues, Marinduque Island, Philippines: Observations from a Joint U.S. Geological Survey - Armed Forces Institute of Pathology Reconnaissance Field Evaluation, May 1219, 2000. U. S. Geological Survey Open-File Report 00397. Available at http://geology.cr.usgs.gov/pub/openfile-reports/ofr-00-0397/

[11] Samaniego JO, Gibaga CRL, Tanciongco AM, Rastrullo RM, Costa, MAV. Surface Water Characteristics in the Vicinity of Abandoned Mercury Mine Site in Puerto Princesa City, Philippines. Philipp. J. Sci. 2019; 148(3): 493-498.

[12] (APHA-AWWA-WEF) American Public Health Association, American Water Works Association, Water Environment Federation. 1998. Standard Methods for the Examination of Water and Wastewater, 20th Ed. Washington, DC. 1325p.

[13] (DENR) Department of Environment and Natural Resources. 2016. Water Quality Guidelines and General Effluent Standards of 2016 [DENR Administrative Order No. 2016-08]. Quezon City, Philippines, Department of Environment and Natural Resources. $25 \mathrm{p}$.

[14] Del Mundo XM, Lumalang LM, Olavidez RM. Assessing heavy metals $\mathrm{Cu}, \mathrm{Mn}$ and $\mathrm{Zn}$ content of soil and water at Consolidated Mines Incorporated (CMI) abandoned mining site in Capayang-Ino, Mogpog, Marinduque. (Undergraduate thesis, 2004) Marinduque State College-Boac, Marinduque.

[15] Kelly CA, Rudd JWM. Transport of mercury on the finest particles results in high sediment concentrations in the absence of significant ongoing sources. Science of the Total Environment 2018; 637-638: 1471-1479.

[16] Samaniego JO, Tanchuling MAN. Physico-chemical Characteristics of Wastewater from a Ball Mill Facility in Small-Scale Gold Mining Area of Paracale, Camarines Norte, Philippines. Philippine Journal of Science 2018; 147(3): 343-356.

[17] Samaniego J, Tanchuling MA. Sedimentation Tests of Small Scale Gold Mining Wastewater. International Journal of Scientific \& Technology Research 2018; 7(6): 73-80. 